\title{
Evaluation of some food additives and heavy metals in Egyptian meat products
}

\author{
Mohamed Abdelfattah Maky1 ${ }^{1}$, Mohamed A. A. Abd-ElRasoul ${ }^{2}$ and Mohammed Salah ${ }^{3}$ (D)
}

1. Department of Food Hygiene and Control, Faculty of Veterinary Medicine, South Valley University, 83522, Qena, Egypt;

2. Central Laboratory, Faculty of Veterinary Medicine, Assiut University, Assiut, Egypt; 3. Department of Biochemistry, Faculty of Veterinary Medicine, South Valley University, 83522, Qena, Egypt.

Corresponding author: Mohammed Salah, e-mail: salah-bio@vet.svu.edu.eg

Co-authors: MAM: mohamedmekky@vet.svu.edu.eg, MAAA: mabdsalam02@gmail.com

Received: 13-01-2020, Accepted: 15-04-2020, Published online: 09-06-2020

doi: www.doi.org/10.14202/IJOH.2020.61-68 How to cite this article: Maky MA, Abd-ElRasoul MAA, Salah M (2020) Evaluation of some food additives and heavy metals in Egyptian meat products, Int. J. One Health, 6(1): 61-68.

\begin{abstract}
Background and Aim: Contamination of processed meat by chemicals, either by their addition for enhancing the product quality or as a result of contamination during the manufacturing process, is a crucial food safety issue that threatens human health. This research was conducted to estimate the contamination levels by harmful chemical contaminants, including nitrite, lead, cadmium, and phosphate in the Egyptian processed meats.
\end{abstract}

Materials and Methods: In our study, 20 samples of each frozen sausage, pastirma, and luncheon were collected and prepared for the detection of chemical contaminants, including nitrite, lead, cadmium, phosphorus, and phosphate.

Results: Pastirma showed the highest nitrite and lead levels $(163.65 \pm 22.633$ and $0.805 \pm 0.173 \mathrm{ppm})$ and the lowest levels in phosphorus and phosphate $(2.294 \pm 0.19$ and $9.084 \pm 0.755 \mathrm{~g} / \mathrm{kg})$ whereas sausage recorded the highest concentration of cadmium $(0.073 \pm 0.008 \mathrm{ppm})$, phosphorus and phosphate $(13.268 \pm 1.129$ and $52.54 \pm 4.472 \mathrm{~g} / \mathrm{kg}$, respectively). However, the estimation of nitrite, lead, cadmium, and phosphate levels in sausage, pastirma, and luncheon was considered within the acceptable daily intake. Moreover, target hazard quotient and hazard index of all analyzed chemical contaminants in different processed meat were below one, indicating the safety of these meat products without any danger to human health. The probability of developing cancer was measured using carcinogenic risk (CR) where pastirma and luncheon recorded satisfactory levels away from developing cancer because of lead (4.59E-04 and 1.87E-04, respectively) and cadmium (7.60E-04 and 3.80E-04, respectively) contamination. Surprisingly, the cadmium level in sausage samples represented a relevant CR for consumers (1.90E-03).

Conclusion: Periodical surveillance of meat chemical contaminants is a vital issue for human health maintenance.

Keywords: carcinogenic risk, chemical contaminants, hazard index, meat products, target hazard quotient.

\section{Introduction}

Meat and its products were considered a rich source of high biological protein, fat, iron, vitamins, phosphorus, and fundamental elements. Although meat products creating a vital role in human nutrition, they may harbor harmful elements [1].

Food additives were extensively used in processed meat manufacturing, as they improve the texture, color, flavor, and taste as well as prolonged the durability $[2,3]$. Nitrite is used in the manufacture of some processed meat as it has various tasks, including fixing the product's red color, enhancing the flavor, inhibiting food biohazards, and retarding fat rancidity [4]. However, nitrite is a precursor of N-nitrosamines, a carcinogenic compound, arisen of nitrite reaction with secondary amines in the digestive system. Moreover, nitrite reduces oxygen

Copyright: Maky, et al. This article is an open access article distributed under the terms of the Creative Commons Attribution 4.0 International License (http://creativecommons.org/licenses/ by/4.0/), which permits unrestricted use, distribution, and reproduction in any medium, provided you give appropriate credit to the original author(s) and the source, provide a link to the Creative Commons license, and indicate if changes were made. The Creative Commons Public Domain Dedication waiver (http:// creativecommons.org/ publicdomain/zero/1.0/) applies to the data made available in this article, unless otherwise stated. transportation in the blood circulation through the oxidation of hemoglobin to methemoglobin [5]. Therefore, consumers are looking for processed meat with very low nitrite concentrations or nitrite-free products [6].

Phosphates are fundamental for normal body growth and maintenance as well as cells and the repair of living organisms. Many kinds of protein-rich foods, including meat naturally contain phosphate that is partially absorbed by the gastrointestinal tract $[7,8]$. The addition of phosphates in processed meat as a food additive is due to several reasons such as stabilizing the $\mathrm{pH}$ value, expanding the shelf-life, improving water holding capacity, and sensory features. Moreover, phosphate is considered the main source of phosphorus, which is an indispensable element for human life [9]. Almost of food additive phosphate is effectively absorbed, so its dietary level should be limited and be at the normal permissible level. Various literature have pointed out the relationship between the high phosphate level and mortality reflects with patients with renal and cardiovascular diseases $[8,10]$.

Heavy metals, the most dangerous pollutants generated by the industry and urbanization, have a serious effect on public health. Therefore, people close contact 
with them through food consumption, particularly meat, and meat-derived products [11]. Heavy metals are extremely toxic and harmful to public health because they are not broken down during meat processing as well as after consumption where they are not metabolized inside the body and bioaccumulate in human tissues. Bioaccumulation of heavy metals depends on several factors, including the organ of concern, bioavailability, metal characteristics, and the age of consumers [12].

Lead and cadmium are toxic heavy metals spreading in the surrounding environment where they are produced during mining, manufacturing, and burning of fossil fuels. They may contaminate food through the air, water, soil, and even during industrial meat processing and packaging. Most of these heavy metals are absorbed and accumulated in the soft tissues $[13,14]$. Lead is mainly deposited in the skeleton of the body, whereas cadmium is mostly accumulated in the brain and renal system. Symptoms of lead poisoning vary from abdominal pain, anemia, nervous signs, and coma, while long-term exposure to cadmium leads to malignancies formation and renal failure $[15,16]$. In European counties, veterinary hygiene and meat safety are highly regulated and numerous legislation has been enacted [17-19].

This research was conducted to estimate the contamination levels by harmful chemical contaminants, including nitrite, lead, cadmium, and phosphate in the Egyptian processed meats. Moreover, the hazards to human health arisen by consumption of contaminated Egyptian processed meat were evaluated through measuring daily intake, hazard index (HI), as well as carcinogenic rate. This study is considered one of the few approaches for investigating the presence of these chemical contaminants in Egyptian processed meats and the first in upper Egypt.

\section{Materials and Methods}

Ethical approval

There is no need of the ethical approval for this work. Samples were collected from the markets. All experiments were done at the Biochemistry and Meat Hygiene laboratories, Faculty of Veterinary medicine, South Valley University, Qena, Egypt.

\section{Collection of samples}

Sixty samples of widely consumed processed meat products, including luncheon, oriental sausage, and pastirma (20 samples each) were collected from different Egyptian markets from January to May 2017. Frozen sausage samples were collected in its original package while luncheon and pastirma were collected in clean polyethylene bags. The samples were rapidly transferred to the lab in an icebox.

\section{Determination of nitrite}

Residual nitrite was assessed using the spectrophotometer (Unico-UV-2100 spectrophotometer, USA) utilizing Griess reagent at wavelength $540 \mathrm{~nm}$ following the method described by AOAC, 2000 [20].

\section{Determination of lead and cadmium}

From each sample, $2 \mathrm{~g}$ were digested by using a mix of $10 \mathrm{ml}$ of nitric acid (65\%) and $2 \mathrm{ml}$ from perchloric acid in a digestion flask [21]. The flasks were shaken and kept overnight at room temperature. The digestion flasks were placed in a water bath for $3 \mathrm{~h}$ at $70^{\circ} \mathrm{C}$, followed by samples dilution and subjected to the filtration step.

Lead and cadmium were estimated in the digested samples using the atomic absorption spectrophotometer (Buck Scientific Inc. East Norwalk, CT, USA) at wavelength 217 and $228.8 \mathrm{~nm}$ for lead and cadmium, respectively $[22,23]$.

\section{Determination of total phosphorus content}

Five grams of homogenized samples were placed into porcelain crucibles. The ashing of the samples was performed utilizing the muffle furnace. The ash was mixed with nitric acid (1.5\%), then distilled water was added up to $100 \mathrm{ml}$, followed by sample filtration.

Phosphorus was estimated using a spectrophotometer (Unico-UV-2100 spectrophotometer, USA) at $430 \mathrm{~nm}$ wavelength [24]. To convert the phosphorus content to phosphate, phosphorus value was multiplied to 3.96 [25]. Natural phosphate was calculated by multiplying \% of product protein to 250 [26]. The average protein percentage in Egyptian processed meat is $14.15 \%, 15.96 \%$, and $17.99 \%$ for luncheon, pastirma, and sausage, respectively, as previously reported [27].

\section{Estimation of daily intake (EDI) of chemical contaminant}

The EDI of lead, cadmium, nitrite, and phosphate was calculated using the following equation [28]:

$$
\mathrm{EDI}=\frac{\mathrm{MC} \times \mathrm{FDC}}{\mathrm{BW}}
$$

MC: Mean concentration of contaminated in processed meat $(\mu \mathrm{g} / \mathrm{g})$.

FDC: Average daily intake of processed meat products, it was considered to be $4 \mathrm{~g} /$ person/day [29].

BW: Average body weight (60 kg).

\section{Evaluation of human health risk}

Target hazard quotient (THQ)

The THQ displayed possible health hazards from the ingestion of contaminated food. THQ was determined based on the method displayed in USEPA risk-based concentration table [30], according to the following equation:

$$
\mathrm{THQ}=\frac{\mathrm{EFr} \times \mathrm{ED} \times \mathrm{FDC} \times \mathrm{MC}}{\mathrm{RfD} \times \mathrm{BW} \times \mathrm{AT}} \times 10^{-3}
$$

EFr: Exposure frequency (365 days/year), ED: The exposure duration (70 years), FDC: Average daily intake of processed meat products, it was considered to be $4 \mathrm{~g} /$ person/day [29], RfD: Oral reference dose (lead = $0.004 \mu \mathrm{g} / \mathrm{g}$ bw/day, cadmium $=0.001 \mu \mathrm{g} / \mathrm{g}$ bw/day, nitrite $=0.1 \mu \mathrm{g} / \mathrm{g}$ bw/day) [30,31], MC: Mean concentration of contaminant $(\mu \mathrm{g} / \mathrm{g})$, BW: Body weight $(60 \mathrm{~kg})$, $\mathrm{AT}$ : Is the average exposure time ( 365 days $\times$ number of exposure years, supposing 70 years in this work). 


\section{Determination of $H I$}

HI is indicated as the THQ. HI $=$ THQ (lead) + THQ (cadmium) + THQ (nitrite).

\section{Estimation of carcinogenic risk (CR)}

$\mathrm{CR}$ is the probability of an individual for getting cancer during life as a result of exposure to a carcinogen. CR for lead and cadmium was estimated utilizing the cancer slope factor (CSF), as described by the US EPA [32] using the following calculation:

$$
\mathrm{CR}=\mathrm{CSF} \times \mathrm{EDI}
$$

CSF: Carcinogenic slope factor was $0.0085(\mathrm{mg} / \mathrm{kg} / \text { day })^{-1}$ for lead and $0.38(\mathrm{mg} / \mathrm{kg} / \text { day })^{-1}$ for cadmium as showed by USPEA [32]. EDI: Estimated daily intake of studied elements.

\section{Statistical analysis}

The analysis of the results was performed utilizing analysis of variance using SPSS 16.0. (SPSS Inc, Chicago, Illinois, USA). Significance was described at $\mathrm{p} \leq 0.05$.

\section{Results}

\section{Measurement of residual nitrite content in Egyptian processed meat}

In the present work, we first measured the concentration of residual nitrite content in Egyptian processed meat. Pastirma expressed the highest concentration of residual nitrite $(163.65 \pm 22.633 \mathrm{ppm})$, followed by luncheon (136.15 $\pm 8.16 \mathrm{ppm})$, while sausage showed the lowest $(106.88 \pm 18.816 \mathrm{ppm})$. The residual nitrite level between pastirma and sausage samples was significantly different $(\mathrm{p} \leq 0.05$; Table- 1$)$.

\section{Determination of heavy metals in Egyptian processed meat}

Next, we attempted to determine the level of lead and cadmium in Egyptian processed meat, including luncheon, pastirma, and sausage. Our findings exhibited that pastirma samples expressed the highest lead concentration level $(0.805 \pm 0.173 \mathrm{ppm})$, followed by luncheon $(0.337 \pm 0.077 \mathrm{ppm})$, while sausage samples

Table-1: Statistical analytical results of residual nitrite levels (ppm) in examined meat products.

\begin{tabular}{lccc}
\hline Product & Minimum & Maximum & Mean \pm SE \\
\hline Sausage & 12.46 & 276.23 & $106.88 \pm 18.816^{\mathrm{a}}$ \\
Pastirma & 26.93 & 345.23 & $163.65 \pm 22.633^{\mathrm{b}}$ \\
Luncheon & 79.24 & 198.32 & $136.15 \pm 8.16$ \\
\hline
\end{tabular}

Means with different superscripts at the same column are significantly different at $p \leq 0.05$ recorded the lowest level $(0.081 \pm 0.007 \mathrm{ppm}$; Table-2). The lead concentration between all groups was significantly different $(\mathrm{p} \leq 0.05)$.

Concerning the cadmium level, the obtained data exhibited that sausage samples expressed the highest cadmium concentration level $(0.073 \pm 0.008)$, followed by pastirma $(0.029 \pm 0.001)$, while luncheon samples showed the lowest level $(0.016 \pm 0.002 \mathrm{ppm}$; Table-2). Cadmium concentration between all groups was significantly different $(\mathrm{p} \leq 0.05)$.

\section{Evaluation of phosphorus and phosphate level in Egyptian processed meat}

We further evaluated the total phosphorus and phosphate content of Egyptian processed meat, as shown in Table-3. Sausage samples showed the highest phosphorus and phosphate content $(13.268 \pm 1.129 \mathrm{~g} / \mathrm{kg}$ and $52.54 \pm 4.472 \mathrm{~g} / \mathrm{kg}$, respectively), followed by luncheon $(9.213 \pm 1.063 \mathrm{~g} / \mathrm{kg}$ and $36.49 \pm 4.211 \mathrm{~g} / \mathrm{kg}$, respectively), while pastirma showed the lowest content $(2.294 \pm 0.19 \mathrm{~g} / \mathrm{kg}$ and $9.084 \pm 0.755 \mathrm{~g} / \mathrm{kg}$, respectively). Phosphorus and phosphate contents were statistically different between different meat products $(\mathrm{p} \leq 0.05)$.

Natural phosphate concentration was calculated in different meat products by multiplying the percentage of protein in each product to 250 (Table-4). Added phosphate was measured by subtracting the percentage of natural phosphate from a percentage of total phosphate where sausage showed the highest percentage of added phosphate, followed by luncheon then pastirma $(4.804 \%, 3.295 \%$, and $0.509 \%$, respectively; Table-4).

\section{Evaluation of human health risk in Egyptian processed meat}

Finally, we evaluated that different human health risk indicators such as EDI, HI, and CR EDI of chemical contaminants associated with the consumption of Egyptian processed meat are shown in Table-5. The higher daily intake of lead, nitrite, and phosphate could be occurred by consumption of pastirma $(0.054 \mu \mathrm{g} / \mathrm{kg}$ bw/day, $10.91 \mu \mathrm{g} / \mathrm{kg}$ bw/day, and $3502.667 \mu \mathrm{g} / \mathrm{kg}$ bw/day, respectively) while sausage exhibited the highestcadmium daily intake (0.005) compared to pastirma and luncheon $(0.002 \mu \mathrm{g} / \mathrm{kg}$ bw/day and $0.001 \mu \mathrm{g} / \mathrm{kg}$ bw/day, respectively). In addition, THQ and HI were calculated in different meat products (Table-6) where THQ for nitrite was greater than lead and cadmium in all examined samples. While pastirma showed the highest THQ for lead (0.013), whereas sausage showed the highest THQ in cadmium

Table-2: The concentration (ppm) of lead and cadmium in different meat products.

\begin{tabular}{|c|c|c|c|c|c|c|}
\hline \multirow[t]{2}{*}{ Product } & \multicolumn{3}{|c|}{ Lead } & \multicolumn{3}{|c|}{ Cadmium } \\
\hline & Minimum & Maximum & Mean \pm SE & Minimum & Maximum & Mean \pm SE \\
\hline Sausage & 0.022 & 0.126 & $0.081 \pm 0.007^{a}$ & 0.014 & 0.115 & $0.073 \pm 0.008^{a}$ \\
\hline Pastirma & 0.15 & 1.636 & $0.805 \pm 0.173^{b}$ & 0.019 & 0.04 & $0.029 \pm 0.001^{b}$ \\
\hline Luncheon & 0.015 & 0.965 & $0.337 \pm 0.077^{c}$ & 0.002 & 0.027 & $0.016 \pm 0.002^{c}$ \\
\hline
\end{tabular}

Means with different superscripts at the same column are significantly different at $p \leq 0.05$ 


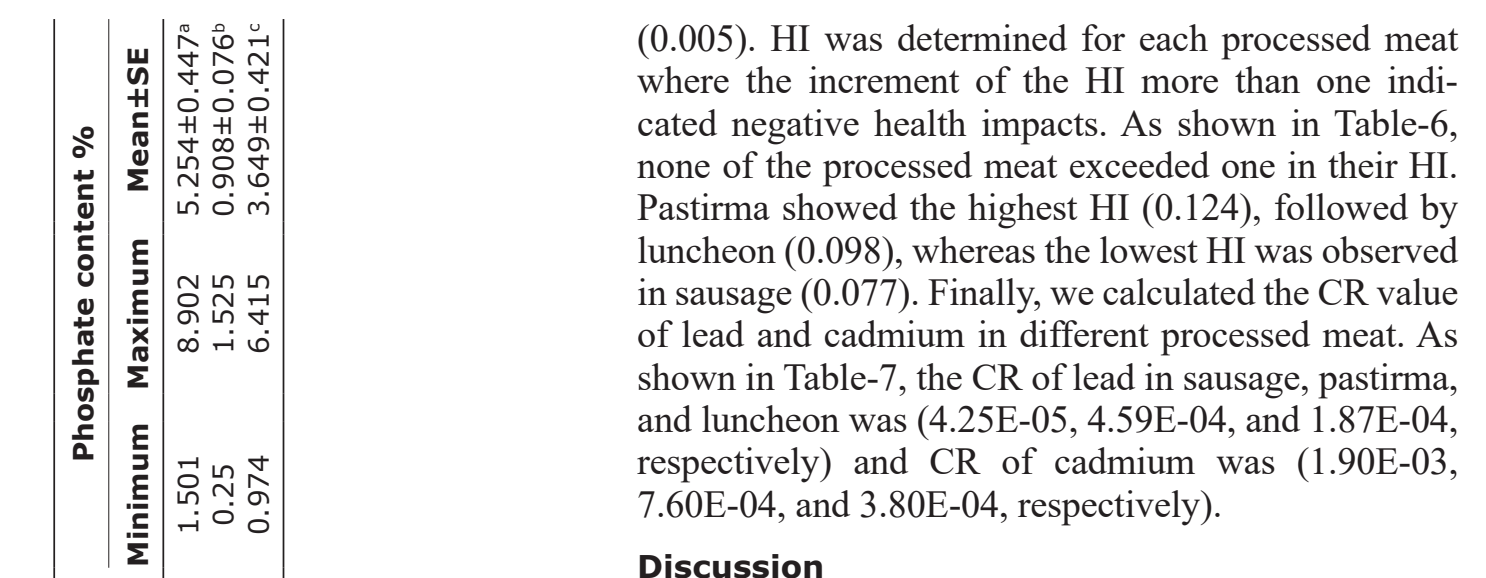

(0.005). HI was determined for each processed meat where the increment of the HI more than one indicated negative health impacts. As shown in Table-6, none of the processed meat exceeded one in their HI. Pastirma showed the highest HI (0.124), followed by (n) in sausage (0.077). Finally, we calculated the $C R$ value and luncheon was $(4.25 \mathrm{E}-05,4.59 \mathrm{E}-04$, and 1.87E-04, respectively) and CR of cadmium was (1.90E-03,

\section{Discussion}

The hazards correlated with meat and their products, particularly the chemical ones, should be supervised to ensure consumer safety [33]. Food contamination is a matter of crucial dilemma, as the presence of high levels of these chemicals may cause severe health hazards and the periodical control of these contaminants will minimize these threats [34]. Nitrite is commonly used in processed meat as a curing compound and it could retard the growth of Clostridium botulinum [35]. After the addition of nitrite to meat, it reacted with myoglobin to fix the red color, the nitrite that not combine with myoglobin became the residual nitrite [36]. In the present study, nitrite concentration in different Egyptian meat products was measured and compared to its permissible limit (100 ppm) that was indicated by Egyptian standard specification [37] and FAO/WHO [26]. Pastirma showed the highest levels of nitrite compared to luncheon and sausage. The percentage of samples that showed residual nitrite above the permissible limit was 50,60 , and $85 \%$ for sausage, pastirma, and luncheon, respectively (Figure-1). This result match with a previous study done by Kassem and Zahran, 2011 [38] where they determined the residual nitrite content of Egyptian meat products, including luncheon, frankfurter, oriental sausage, and pastirma and reported that the highest residual nitrite level was detected in the pastirma samples. The elevated residual nitrite in pastirma could be regarded

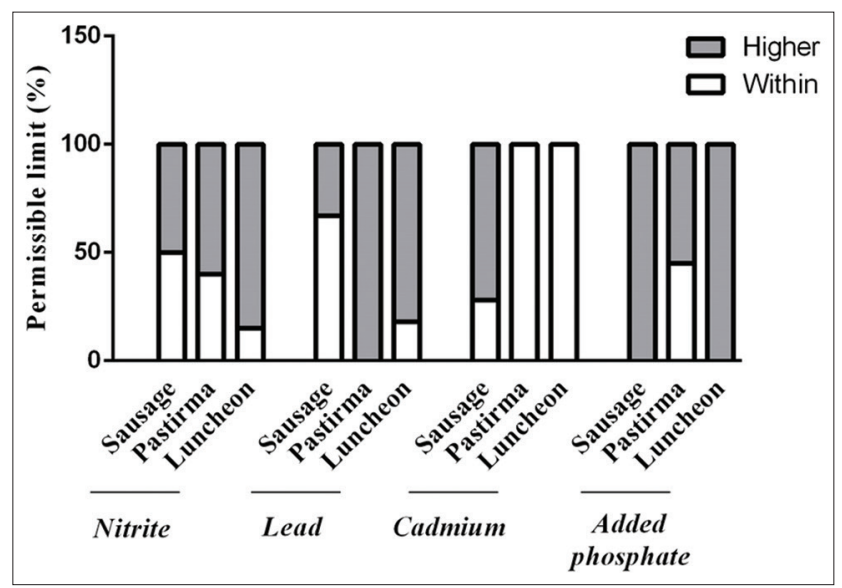

Figure-1: Percentage of permissible limit of some meat contaminants in different Egyptian meat products. 
Table-4: The percentage of natural phosphate and the added phosphate in Egyptian processed meat.

\begin{tabular}{lccc}
\hline Products & $\begin{array}{c}\text { Natural phosphate } \mathbf{~} \mathbf{p g} / \mathbf{k g} \\
(\mathbf{2 5 0} \times \mathbf{\%} \text { protein } \mathbf{)}\end{array}$ & Natural phosphate \% & $\begin{array}{c}\text { Added phosphate\% (Total phosphate } \\
\text { \% - natural phosphate \%) }\end{array}$ \\
\hline Sausage & 4499.2 & 0.45 & 4.804 \\
Pastirma & 3990.8 & 0.399 & 0.509 \\
Luncheon & 3537.5 & 0.354 & 3.295 \\
\hline
\end{tabular}

The average protein percentage in Egyptian processed meat was 14.15\%, 15.96\%, and 17.99\% for luncheon, pastirma, and sausage, respectively.

Table-5: The estimated daily intake of chemical contaminants in examined meat products ( $\mu \mathrm{g} / \mathrm{kg}$ bw/day).

\begin{tabular}{lcccc}
\hline Product & \multicolumn{3}{c}{ Element } \\
\cline { 2 - 5 } & Lead & Cadmium & Nitrite & Phosphate \\
\hline Sausage & 0.005 & 0.005 & 7.125 & 2432.667 \\
Pastirma & 0.054 & 0.002 & 10.91 & 3502.667 \\
Luncheon & 0.022 & 0.001 & 9.077 & 605.6 \\
Acceptable daily intake & 3.6 & 1 & 60 & 70000 \\
\hline
\end{tabular}

Table-6: THQ of chemical contaminants through consumption of meat products.

\begin{tabular}{lcccc}
\hline Product & \multicolumn{3}{c}{ Element } & HI \\
\cline { 2 - 4 } & Lead & Cadmium & Nitrite \\
\hline Sausage & 0.001 & 0.005 & 0.071 & 0.077 \\
Pastirma & 0.013 & 0.002 & 0.109 & 0.124 \\
Luncheon & 0.006 & 0.001 & 0.091 & 0.098 \\
\hline
\end{tabular}

Table-7: The carcinogenic risk of lead and cadmium through the consumption of meat products.

\begin{tabular}{lcc}
\hline Product & \multicolumn{2}{c}{ Element } \\
\cline { 2 - 3 } & Lead & Cadmium \\
\hline Sausage & $4.25 \mathrm{E}-05$ & $1.90 \mathrm{E}-03$ \\
Pastirma & $4.59 \mathrm{E}-04$ & $7.60 \mathrm{E}-04$ \\
Luncheon & $1.87 \mathrm{E}-04$ & $3.80 \mathrm{E}-04$ \\
\hline
\end{tabular}

to the uncooked selling status of the product where the salt is added during the curing step to avoid the development of anaerobic bacteria and generating an attractive red color. The lower residual nitrite concentration in luncheon in comparison with pastirma might be related to the impact of heat treatment during luncheon processing [39] whereas the reduction in sausage nitrite level could be attributed to the low amount of added nitrite salt since the frozen sausage is preserved by freezing, followed by cooking by the consumer before consumption.

The existence of high levels of heavy metals in processed meat could have prominent hazards on human health since they represent a part of their daily diet [40]. Accordingly, we evaluated the concentration of heavy metals, particularly lead and cadmium in Egyptian processed meat and study whether these levels exceeded the permissible limits reported by official authorities.

Our findings reported that pastirma and sausage expressed the highest concentration of lead and cadmium, respectively, whereas sausage and luncheon showed the lowest concentration of lead and cadmium, respectively. Concerning to the permissible level of lead, it was noticed that 33,100 , and $82 \%$ of examined sausage, pastirma, and luncheon samples, respectively, exceeded the maximum allowable limit $(0.10 \mathrm{mg} / \mathrm{kg})$ while cadmium level did not exceed the permissible limit $(0.050 \mathrm{mg} / \mathrm{kg})$ in all detected pastirma and luncheon sample. However, $72 \%$ of sausage samples showed a high level of cadmium compared to the accepted permissible level reported by official authorities [41,42]; (Figure-1). A higher value for lead $(0.35 \mathrm{mg} / \mathrm{kg})$ was determined in examined sausage samples [43]. The lead content was ranged from 0.52 to $1.19 \mu \mathrm{g} / \mathrm{g}$, while lower cadmium range $(0.06-0.10 \mu \mathrm{g} / \mathrm{g})$ was detected in various categories of chicken luncheon meat collected from Iraq markets [44].

In addition, Obeid et al. [45] reported that the mean value for lead and cadmium was $0.0174 \mu \mathrm{g} / \mathrm{g}$ and $0.002386 \mu \mathrm{g} / \mathrm{g}$, respectively in Lebanon processed meat samples.

Moreover, an Egyptian study was performed by Khalafalla et al. [46], in muscle, liver, and kidney samples extracted from different beef carcasses showed that all heavy metals including lead, cadmium, mercury, arsenic, chromium, and nickel were within the permissible limits reported by official organizations. The excessive level of lead in the Egyptian processed meat could be referred to fuel burning and wastes removal that releases lead in the form of suspended particles that further pollute water and feeding stuff of animals and subsequently depositing in their muscles [47]. Accumulation of lead may cause impairments of the urinary system, liver, and nervous system. People are generally subjected to lead through food and children are at the greatest danger because $50 \%$ of their ingested lead is absorbed, while only $10-15 \%$ is absorbed in adult [48]. Furthermore, ingestion of lead and cadmium may hinder fetal development and cause immunological impairment due to the lack of some vital micronutrients [23].

Phosphorus is an important element as it has a role in building the bones and nucleic acids [49]. 
However, high levels of phosphorus in processed meat can extremely harm the safety of processed meat. Phosphate as a food additive is allowed to be added in various processed meat but the controlling authorities limit the overall quantity of phosphates in meat products. Our data revealed that sausage significantly recorded the highest phosphorus and phosphate content compared to luncheon and pastirma. Pastirma showed the lowest levels of phosphorus and phosphate.

The highest permissible level for added phosphates is $0.5 \%$, as reported by FAO [26] for processed meat. After calculating the obtained percentage of added phosphate, it was clear that all sausage and luncheon samples exceeded the acceptable level of added phosphate, while only $55 \%$ of pastirma samples showed added phosphate levels higher than the indicated permissible limit (Figure-1). The previous study reported that the percentage of phosphate in some meat products, particularly sausage exceeded the permissible limit recommended by authorities [50]. The high intake of phosphate in processed meat leads to cardiac hypertrophy, atherosclerosis, impairment of endothelial, renal affections, and mortalities [51].

The assessment of the risk after ingestion of food containing hazardous chemicals is a critical issue. The determination of the dietary intake of such chemical agents reflects the hazards affecting human health. The estimated daily intake of lead, cadmium, nitrite, and phosphate of Egyptian processed meat was leaser than the acceptable daily intake established by authorities $[32,52,53]$. It was stated that the daily dietary intake of cadmium was $7 \mu \mathrm{g} /$ day in Spain [54] and $6.4 \mu \mathrm{g} /$ day in France [55].

THQ is considered an indication for determining the hazards associated with elements intake by consumption of contaminated food, where its level higher than one indicates that the individual exposed is susceptible to negative health impacts [30]. THQ and HI of lead, cadmium, and nitrite in different meat were below one, which pinpointed the lack of health hazards. Recent research examined the presence of toxic metals such as lead, cadmium, and mercury in different organs of different animal species where they showed that THQ and HI were below one, suggesting no risk can affect human health beyond the consumption of meat and offal [56]. Our obtained results do not substantially reflect the status of health due to the consumption of Egyptian processed meat, as it was supposed that THA is not a sharp demarcation between secure and insecure exposure for chemical contaminants [57].

CR value is the probability of an agent to cause malignancies. According to USEPA [32], reduction of this value lower than E-6 was considered insignificant and safe and its elevation greater than E-4 was considered undesirable, whereas the value among E-6 to E-4 was considered satisfactory. The CR for cadmium exhibited greater levels than the acceptable limit after consumption of sausage, whereas pastirma and luncheon samples recorded satisfactory levels. While lead values of sausage, pastirma, and luncheon were considered within the satisfaction level as well. Hernández et al. [58], mentioned that the ingestion of meat of different animal species has a CR for consumers with increasing the susceptibility to develop cancers.

\section{Conclusion}

The outcome of the current work showed that pastirma recorded the highest levels of nitrite and lead and the lowest levels of phosphorus and phosphate whereas, sausage samples displayed the highest concentration of cadmium, phosphorus, and phosphate and the lowest concentration of nitrite and lead. All chemical contaminants in different meat products were considered within the permissible daily intake. Moreover, the HI of these contaminants was lower than one and under the hazard level. However, CR of cadmium in sausage only exceeded the desirable rates while lead represented lower levels than developing cancer in different meat products. Finally, appropriate steps should be taken to control the presence of these chemicals during meat processing to reduce the health hazards, particularly the $\mathrm{CR}$ after the consumption of these products.

\section{Authors' Contributions}

All authors participated in the conception and design of the study. MAM and MS collected and prepared the samples for analysis. Samples were analyzed by MS, MAM, and MAAA. Data were statistically manipulated and interpreted by MAM and MS. All authors read, revised, and approved the final manuscript.

\section{Acknowledgments}

This research did not receive any financial support from funding agencies in the public, commercial, or not for profit sectors. The authors are grateful to the Department of Biochemistry and Food Hygiene and Control, Faculty of Veterinary Medicine, South Valley University, for allowing us to use their laboratories to carry out this experiment.

\section{Competing Interests}

The authors declare that they have no competing interests.

\section{Publisher's Note}

Veterinary World (Publisher of International Journal of One Health) remains neutral with regard to jurisdictional claims in published institutional affiliation.

\section{References}

1. Akan, J.C., Abdulrahman, F.I., Sodipo, O.A. and Chiroma, Y.A. (2010) Distribution of heavy metals in the liver, kidney and meat of beef, mutton, caprine and chicken from Kasuwan Shanu market in Maiduguri Metropolis, 
Borno State, Nigeria. Res. J. Appl. Sci. Eng. Technol., 2(8): 743-748.

2. Aymerich, T., Picouet, P.A. and Monfort, J.M. (2008) Decontamination technologies for meat products. Meat Sci. 78(1-2): 114-129.

3. Bondoc, I. (2007) In: de la Brad II, editor. Tehnologia șş Controlul Calităţii Laptelui șş Produselor Lactate. Vol. 1. Iapi Publishing, Romania.

4. Zahran, D.A. and Kassem, G.M.A. (2011) Residual nitrite in some Egyptian meat products and the reduction effect of electron beam irradiation. Adv. J. Food Sci. Technol., 3(5): 376-380.

5. Keszler, A., Piknova, B., Schechter, A.N. and Hogg, N. (2008) The reaction between nitrite and oxyhemoglobin: A mechanistic study. J. Biol. Chem., 283(15): 9615-9622.

6. Bondoc, I. and Șindilar, E.V. (2002) In: de la Brad II, editor. Controlul Sanitar Veterinar al Calității și Salubrităţii Alimentelor. Vol. 1. Iapi Publishing, Romania.

7. Noori, N., Sims, J.J., Kopple, J.D., Shah, A., Colman, S., Shinaberger, C.S., Bross, R., Mehrotra, R., Kovesdy, C.P. and Kalantar-Zadeh, K. (2010) Organic and inorganic dietary phosphorus and its management in chronic kidney disease. Iran. J. Kidney Dis., 4(2): 89-100.

8. Ritz, E., Hahn, K., Ketteler, M., Kuhlmann, M.K. and Mann, J. (2012) Phosphate additives in food--a health risk. Dtsch. Arztebl. Int., 109(4): 49-55.

9. Long, N.H.B., Gál, R. and Buňka, F. (2011) Use of phosphates in meat products. Afr. J. Biotechnol., 10(86): 19874-19882.

10. Tonelli, M., Sacks, F., Pfeffer, M., Gao, Z. and Curhan, G; Cholesterol and Recurrent Events Trial Investigators. (2005) Relation between serum phosphate level and cardiovascular event rate in people with coronary disease. Circulation, 112(17): 2627-2633.

11. Harmanescu, M., Alda, L., Bordean, D., Gogoasa, I. and Gergen, I. (2011) Heavy metals health risk assessment for population via consumption of vegetables grown in old mining area; a case study: Banat County, Romania. Chem. Cent. J., 5: 64.

12. Vasile, H.G., Elena, C., Ana, L. and Pararin, B. (2014) Heavy metals contamination levels in processed meat marketed in Romania. Environ Eng. Manag. J., 13(9): 2411-2415.

13. Binkowski, L.J. (2012) Is the meat of wild waterfowl fit for human consumption? Preliminary results of cadmium and lead concentration in pectoral muscles of mallards and coots shot in 2006 in Southern Poland. J. Microbiol. Biotechnol. Food Sci. 1: 1120-1128.

14. Islam, M.S., Ahmed, M.K., Al-Mamun, M.H. and Raknuzzaman, M. (2015) The concentration, source and potential human health risk of heavy metals in the commonly consumed foods in Bangladesh. Ecotoxicol. Environ. Saf., 122: 462-469.

15. Rahimzadeh, M.R., Rahimzadeh, M.R., Kazemi, S. and Moghadamnia, A.A. (2017) Cadmium toxicity and treatment: An update. Caspian J. Intern. Med., 8(3): 135-145.

16. World Health Organization. (2016) Lead Poisoning and Health. World Health Organization, Geneva.

17. Bondoc, I. (2016) European Regulation in the Veterinary Sanitary and Food Safety Area, a Component of the European Policies on the Safety of Food Products and the Protection of Consumer Interests: A 2007 Retrospective. Part Two: Regulations. Universul Juridic, Supliment, 16-19. Available from: http://www.revista.universuljuridic.ro/supliment/ european-regulation-veterinary-sanitary-food-safety-area-component-european-policies-safety-food-products-protection-consumer-interests-2007-retrospective-2. Retrieved on 01-04-2020.

18. Bondoc, I. (2016) European Regulation in the Veterinary Sanitary and Food Safety Area, a Component of the European Policies on the Safety of Food Products and the Protection of Consumer Interests: A 2007 Retrospective. Part Three: Directives. Universul Juridic, Supliment, 20-23. Available from: http://www.revista.universuljuridic.ro/supliment/ european-regulation-veterinary-sanitary-food-safety-area-component-european-policies-safety-food-products-protection-consumer-interests-2007-retrospective-part. Retrieved on 01-04-2020.

19. Bondoc, I. (2016) European Regulation in the Veterinary Sanitary and Food Safety Area, a Component of the European Policies on the Safety of Food Products and the Protection of Consumer Interests: A 2007 Retrospective. Part Four: Decisions. Universul Juridic, Supliment, 24-27. Available from: http://www.revista.universuljuridic.ro/supliment/ european-regulation-veterinary-sanitary-food-safety-area-component-european-policies-safety-food-products-protection-consumer-interests-2007-retrospective-part-2. Retrieved on 01-04-2020.

20. AOAC. (2000) Official Method of Analysis. 17 $7^{\text {th }}$ ed. Association of Official Analytical Chemists, Washington, DC, USA.

21. Zantopoulos, N., Antoniou, V., Petsaga, V. and Zdrags, A. (1996) Copper concentration in sheep liver and kidney in Greece. Vet. Hum. Toxicol., 38(3): 184-185.

22. Chowdhury, M.Z.A., Siddique, Z.A., Hossain, S.A., Kazi, A.I., Ahsan, A.A., Ahmed, S. and Zaman, M. (2012) Determination of essential and toxic metals in meats, meat products and eggs by spectrophotometric method. J. Bangladesh Chem. Soc., 24(2): 165-172.

23. Solidum, J.M., Vera, M.J.D. De., Abdulla, A.R.D., Evangelista, J.H. and Nerosa, M.J.A. (2013) Quantitative analysis of lead, cadmium and chromium found in selected fish marketed in Metro Manila, Philippines. Int. J. Environ. Sci. Dev., 4(2): 207-211.

24. Korn, M.D.G., da Boa Morte, E.S., dos Santos, D.C.M., Castro, J.T., Barbosa, J.T.P., Teixeira, A.P., Fernandes, A.P., Welz, B., dos Santos, W.P.C., dos Santos, E.B.G. and Korn, M. (2008) Sample preparation for the determination of metals in food samples using spectro analytical methods a review. Appl. Spectrosc. Rev., 43(2): 67-92.

25. United States Department of Agriculture Food Safety and Inspection Service, Office of Public Health Science (2009) Determination of Phosphate. Official Methods of Analysis of the Association of Official Analytical Chemists, $15^{\text {th }}$ Edition, 969.31B. Available from: https://www.fsis.usda. gov/wps/wcm/connect/87172299-2fd3-41fd-aa3a-ca603ce7fcb6/CLG_PHS_1_01.pdf?MOD=AJPERES. Retrieved on 20-05-2020.

26. Food and Agriculture Organization. (1991) Joint FAO/WHO Standards Programme, Codex Alimentarius Commissions. $19^{\text {th }}$ ed. Food and Agriculture Organization, Rome.

27. Sabry, A. (2016) Chemical Composition of Some Egyptian Meat Products. Ph. D. Thesis of Veterinary Medicine, University of Alexandria, Egypt.

28. Zeinali, T., Salmani, F. and Naseri, K. (2019) Dietary intake of cadmium, chromium, copper, nickel and lead through the consumption of meat, liver and kidney and assessment of human health risk in Birjand, Southeast of Iran. Biol. Trace Elem. Res., 191(2): 338-347.

29. GBD 2017 Diet Collaborators. (2019) Health effects of dietary risks in 195 countries, 1990-2017: a systematic analysis for the Global Burden of Disease Study 2017. Lancet. 393(10184):1958-1972.

30. USEPA. (2000) Risk based Concentration Table. United States Environmental Protection Agency, Philadelphia, PA, Washington DC. Available from: http://www.sciepub.com/ reference/13120. Retrieved on 28-08-2019.

31. Pirsaheb, M., Khosravi, T., Sharafi, K. and Mouradi, M. (2016) Comparing operational cost and performance evaluation of electrodialysis and reverse osmosis systems in nitrate removal from drinking water in Golshahr, Mashhad. Desalin. Water Treat., 57(12): 5391-5397.

32. USEPA. (2010) Integrated Risk Information System. (IRIS). United States Environmental Protection. Available from: http://www.epa.gov/iris/index.html. Retrieved on 
28-08-2019.

33. Bondoc, I. (2016) European Regulation in the Veterinary Sanitary and Food Safety Area, a Component of the European Policies on the Safety of Food Products and the Protection of Consumer Interests: A 2007 Retrospective. Part One: The Role of European Institutions in Laying Down and Passing Laws Specific to the Veterinary Sanitary and Food Safety Area. Universul Juridic, Supliment, 12-15. Available from: http://www.revista.universuljuridic.ro/supliment/european-regulation-veterinary-sanitary-food-safety-area-component-european-policies-safety-food-products-protection-consumer-interests-2007-retrospective. Retrieved on 01-04-2020.

34. Rather, I.A., Koh, W.Y., Paek, W.K. and Lim, J. (2017) The sources of chemical contaminants in food and their health implications. Front. Pharmacol., 8: 830.

35. El-Kewaiey, I.A. and Al-Tedawy, F.A. (2012) Determination of sodium nitrite in some locally manufactured meat products. Assiut Vet. Med., 58(32): 1-16.

36. Viuda-Martos, M., Fernández-López, J., Sayas-Barbera, E., Sendra, E., Navarro, C. and Pérez-Alvarez, J.A. (2009) Citrus co-products as technological strategy to reduce residual nitrite content in meat products. J. Food Sci., 74(8): R93-R100.

37. ESS/3598. (2005) Egyptian Standard Specification. Egyptian Standard Specification for Sodium Nitrate Used in Food Products. Egyptian Organization for Standardization and Quality Control, Egypt.

38. Kassem, G.M. and Zahran, D.A. (2011) Residual nitrite in some Egyptian meat products and the reduction. $A d v . J$. Food Sci. Technol., 3(5): 376-380.

39. Khaksar, R., Hosseini, H., Ferdowsi, R., Akhavan, H., Ahmadi, H. and Abbasi, M. (2007) Nitrite residual changes in four types of heated red meat products during storage at 4 degrees centigrade. Iran. J. Nutr. Sci. Food Technol., 2(2): 45-50.

40. Dubey, V.K., Agnihotri, M. and Shukla, A. (2016) Determination of heavy metals in selected meat and meat products from meat market of Singrauli. IOSR J. Appl. Chem., 9(11): 52-54.

41. Egyptian Standards. (2010) Maximum Levels for Certain Contaminants in Foodstuffs. Egyptian Organization for Standardization. ES, No. 7136.

42. European Community. (2006) Setting Maximum Levels for Certain Contaminants in Foodstuffs. Commission Regulations, EC, No. 1881.

43. Sobhanardakani, S. (2018) Analysis of contamination levels of $\mathrm{Cu}, \mathrm{Pb}$, and $\mathrm{Zn}$ and population. Jundishapur J. Health Sci., 10(1): e14059.

44. Hamasalim, H.J. and Mohammed, H.N. (2013) Determination of heavy metals in exposed corned beef and chicken luncheon that sold in Sulaymaniah. Afr. J. Food Sci., 7(7): 178-182.

45. Obeid, P.J., Saliba, C.E., Younis, M., Aouad, S. and
El-Nakat, J. (2014) Determination of levels of lead and cadmium contamination in meat products sold in Northern Lebanese markets. Int. J. Saf. Secur. Eng., 4(4): 329-344.

46. Khalafalla, F.A., Ali, F.H., Schwagele, F. and Abd-ElWahab, M.A. (2011) Heavy metal residues in beef carcasses in Beni-Suef abattoir, Egypt. Vet. Ital., 47(3): 351-361.

47. Ihedioha, J.N. and Okoye, C.O.B. (2012) Cadmium and lead levels in muscle and edible offal of cow reared in Nigeria. Bull. Environ. Contam. Toxicol., 88(3): 422-427.

48. Abou-Arab, A.A. (2001) Heavy metal contents in Egyptian meat and the role of detergent washing on their levels. Food Chem. Toxicol., 39(6): 593-599.

49. Cupisti, A. and Kalantar-Zadeh, K. (2013) Management of natural and added dietary phosphorus burden in kidney disease. Semin. Nephrol., 33(2):180-190.

50. Salim, D.A. and Abou El-Roos, N.A. (2013) Detection of phosphates and hydroxyproline in some meat. Benha Vet. Med. J., 25(1): 1-9.

51. Disthabanchong, S. (2018) Phosphate and cardiovascular disease beyond chronic kidney disease and vascular calcification. Int. J. Nephrol., 2018: 3162806.

52. Dudka, S. and Miller, P. (1999) Accumulation of potentially toxic elements in plants and their transfer to human food chain. J. Environ. Sci. Health B, 34(4): 681-708.

53. ECFA. (1982) Toxicological Evaluations of Certain Food Additives. $26^{\text {th }}$ Report of the Joint FAO/WHO Expert Committee on Food Additives. WHO Food Additives Series. No. 17.

54. Urieta, I., Jalon, M. and Eguileor, I. (1996) Food surveillance in the Basque Country (Spain). II. Estimation of the dietary intake of organochlorine pesticides, heavy metals, arsenic, aflatoxin M1, iron, zinc through the total diet study, 1990/91. Food Addit. Contam., 13(1): 29-52.

55. Biego, G.H., Joyeux, M., Hartemann, P. and Debry, G. (1998) Daily intake of essential minerals and metallic micropollutants from foods in France. Sci. Total Environ., 217(1-2): 27-36.

56. Morshdy, A.M.A., El Bayomi, R.M., Abd El Galil, G.M. and Mahmoud, A.F.A. (2018) Heavy metal concentrations and their risk assessment in marketed slaughtered animals in Sharkia governorate, Egypt. Slov. Vet. Res., 55(20): 103-120.

57. Rodricks, J.V. and Jackson, B.A. (1992) Food constituents and contaminants. In: Lippmann, M. editor. Environmental Toxicants: Human Exposure and their Health Effects. $3^{\text {rd }}$ ed. Van Nostrand Reinhold, New York. p266-298.

58. Hernández, Á.R., Boada, L.D., Almeida-González, M., Mendoza, Z., Ruiz-Suárez, N., Valeron, P.F., Camacho, M., Zumbado, M., Henríquez-Hernández, L.A. and Luzardo, O.P. (2015) An estimation of the carcinogenic risk associated with the intake of multiple relevant carcinogens found in meat and charcuterie products. Sci. Total Environ., 514: 33-41. 